\title{
KAJIAN BISNIS SOSIAL PEDAGANG PERANTARA DALAM UPAYA PENGEMBANGAN HORTIKULTURA DI JAWA BARAT
}

\author{
Anne Charina, Gema Wibawa Mukti, Rani Andriani ${ }^{1}$ \\ Jurusan Sosial Ekonomi Pertanian \\ Universitas Padjadjaran
}

\begin{abstract}
Currently, 90\% of Indonesian small scale agribusiness actors are being faced to the global market era. They are also facing a fast growth rate of global market and the market segmentation phenomenon which expects positive changes and adaptations in the agricultural supply chain. The method that used in this study is case study. The study location was being selected based on its potential of horticulture product.

The study showed that currently the traders have changed their business pattern from a "pure business" to a business which relies more on the partnership with the farmers. This phenomenon was being emerged by the consumer demand which expects the continuity of supply.

From the "Social Business" aspect point of view, generally the traders do the partnership system because of their needs of continuity of supply from the farmers, not based on helping the farmers. The result of weighting showed the total score placed between $28-32,5$ which means it can be categorized as a semi-social business.

Overall, the study showed that currently the changes are happening in the traders business pattern, thus, it gives hopes to the agricultural development in Indonesia especially for horticulture products of small scale stakeholders.
\end{abstract}

Keywords: Global market, traders, horticulture, social business.

\footnotetext{
${ }^{1}$ Ketiganya merupakan Staf Pengajar Jurusan Sosial Ekonomi Pertanian Unpad
} 


\section{PENDAHULUAN}

Aktivitas pertanian tidak bisa dilepaskan dari kegiatan budi daya pertanian serta perdagangan hasil dari aktivitas tersebut. Pada masa lalu perdagangan hasil pertanian mungkin bukan aktivitas utama karena pertanian yang masih bersifat subsisten sehingga pelaku usaha pertanian pada masa lalu tidak memikirkan aktivitas perdagangan. Namun hal tersebut saat ini telah berubah, dimana komoditas pertanian telah berubah menjadi komoditas komersial. Aktivitas pemasaran atau perdagangan menjadi sesuatu hal yang penting dalam kegiatan usahatani.

Dilihat dari konteks

ekonomi, saat ini sistem pertanian telah beralih dari sistem pertanian yang subsisten dengan skala mikro dengan luas lahan yang kecil ke sistem pertanian dengan perusahaan agribisnis skala besar yang pasar produknya tersebar di berbagai Negara. Meskipun demikian di Negara berkembang, khususnya Indonesia, pertanian skala kecil masih tetap memegang peranan yang sentral ( Von Braun, 2007). Sektor ini masih tetap menjadi andalan pemerintah dalam penyerapan tenaga kerja dan masih memegang peranan penting dalam hal mendukung ketahanan pangan dari negara negara berkembang seperti Indonesia yang merupakan bagian terbesar dari penduduk dunia.
Kehadiran ACFTA per 1 januari 2010 telah menjadi "warning" bagi pelaku usaha dalam bidang pertanian, karena semakin banyaknya produk hortikultura dari luar yang masuk ke dalam negeri dan mengancam produk petani kita. Kondisi ini merupakan ancaman bagi eksistensi pelaku pertanian skala kecil yang merupakan mayoritas usahatani negara negara berkembang. Adanya halangan untuk masuk (barier to entry ) tentunya mengurangi daya saing ekspor dari para pelaku pertanian kita, terutama yang berskala kecil, karena mereka tidak dapat melawan modal besar dari para pengusaha skala besar.

Secara umum, dampak dari pasar global saat ini adalah menyebabkan tekanan yang lebih besar bagi pelaku usaha pertanian skala kecil karena negara - negara maju yang pangsa pasarnya sangat besar enggan memotong subsidi pertanian yang ternyata selama ini lebih tinggi dari subsidi yang diberikan oleh negara - negara berkembang (Bouet et al, 2007). Di Indonesia, hampir $90 \%$ adalah pelaku usaha pertanian dengan skala kecil yang kini dihadapkan pada era pasar global. Peluang dan ancaman terpenting bagi para pelaku usaha pertanian skala kecil berasal dari: (i) implikasi liberalisasi perdagangan internasional, dan (ii) implikasi dari perubahan iklim (Cline, 2007), (Easterling et al, 2007). 


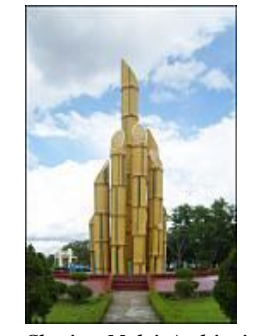

Charina, Mukti, Andriani Kajian Bisnis Sosial Pedagang....
Di sisi lain, kekuatan ataupun kelemahan pertanian di Indonesia terkait dengan skala pengusahaan, penguasaan teknologi pra panen - pasca panen, permodalan, manajemen produksi dan pemasaran (input maupun output).

Periode Januari Agustus 2010, total ekspor Indonesia mencapai US\$ 98,7 M, naik 40,42 \% dibandingkan dengan periode yang sama pada tahun 2009. Namun khusus hortikultura tampaknya volume impor masih lebih tinggi dibandingkan dengan ekspor.
Realisasi volume ekspor produk hortikultura semester I/2010 tercapai sebesar 77,6 juta kilogram, senilai US\$ 80,654 juta sementara volume impor mencapai 367,1 juta kilogram, senilai US\$271,4 juta (Departemen Perdagangan, 2010). Kenyataan ini ternyata disadari oleh para petani maupun pedagang yang terlibat dalam bisnis hortikultura, dimana produk lokal semakin kalah oleh produk impor, sedangkan produk lokal tersebut semakin sulit menembus pasar ekspor ataupun pasar modern di dalam negeri..

Tabel 1. Ekspor Impor Produk Hortikultura

\begin{tabular}{|l|r|r|r|r|}
\hline \multirow{2}{*}{ Komoditas } & \multicolumn{2}{|c|}{2009} & \multicolumn{2}{c|}{2010} \\
\cline { 2 - 5 } & Ekspor (Ton) & Impor (Ton) & Ekspor (Ton) & Impor(Ton) \\
\hline Bawang Merah & 12822 & 67330 & 13871 & 64247 \\
\hline Kentang & 6900 & 46364 & 8132 & 50358 \\
\hline Cabe & 7017 & 17988 & 8774 & 18358 \\
\hline Durian & 21 & 28935 & 15 & 27097 \\
\hline Jeruk & 1310 & 216935 & 1266 & 185580 \\
\hline Manggis & 11319 & 10 & 14951 & 4 \\
\hline Pisang & 710 & 328 & 855 & 1552 \\
\hline Mangga & 1616 & 821 & 1585 & 1103 \\
\hline Anggrek & 122 & 64 & 107 & 43 \\
\hline Biofarmaka & 13088 & 1153 & 13572 & 1244 \\
\hline
\end{tabular}

Sumber : Direktorat Jenderal Hortikultura, 2010

Apabila dilihat dari kondisi yang ada tersebut, maka pasar global ini selain dapat mengancam eksistensi pelaku usaha pertanian skala kecil, namun juga memberikan peluang pasar yang baru bagi mereka. Sejatinya, pasar bebas merupakan peluang besar bagi produk nasional untuk memperoleh pangsa pasar yang lebih besar lagi. Pasar ekspor produk hortikultura yang cukup potensial adalah Singapura dengan permintaan 400 ribu ton/tahun, hongkong dan juga Negara-negara wilayah timur tengah. Saat ini permintaan pasar 
telah berubah ke arah produk pertanian, bukan lagi komoditas pertanian, dimana kualitas maupun nilai menjadi bahan pertimbangan utama bagi seorang konsumen untuk membeli produk pertanian.

Peluang tersebut akan menjadi sesuatu hal yang sia sia jika para pelaku usaha yang terlibat dalam bidang hortikultura tidak menyiapkan diri secara maksimal. Lahirnya kesepakatan antarmenteri pertanian dan kehutanan seASEAN ke - 32 tentang pengetatan syarat ekspor impor, seperti ASEAN Phytosanitary Guidelines untuk produk bunga dan penerapan batas maksimum residu pada produk hortikultura serta penerapan standar untuk buah - buahan akan menyulitkan produk nasional untuk bersaing dalam memperbutkan pasar ekspor. Pengetatan syarat ekspor impor pada dasarnya dapat meningkatkan mutu produk pertanian lokal, karena tuntutan pasar yang mensyaratkan hal tersebut, sehingga petani maupun pedagang akan selalu berusaha untuk memenuhi permintaan konsumen tersebut.

Secara umum, pelaku usaha pertanian yang ada saat ini pada dasarnya telah menyadari kondisi ini, namun akses mereka yang masih sangat terbatas terhadap teknologi, permodalan dan juga informasi - informasi yang mereka butuhkan dalam kegiatan usaha tani membuat mereka belum mampu untuk menciptakan produk pertanian yang sesuai dengan kebutuhan konsumen. Selain itu keterbatasan lahan juga membuat mereka kesulitan untuk melakukan rotasi tanam yang memungkinkan mereka mengirim produk pertanian secara kontinu kepada para konsumen. Aspek kontinuitas yang menjadi salah satu perhatian utama dari konsumen global saat ini tampaknya belum sepenuhnya dapat dipenuhi oleh para petani di Indonesia.

Namun demikian, keberhasilan sector pertanian dalam menjawab kondisi ini tentunya tidak semuanya dibebankan kepada petani, tapi harus dibebankan kepada semua stakeholder yang terkait dengan hal ini, seperti pemerintah dan juga pedagang perantara. Akses petani terhadap informasi, baik itu informasi pasar maupun informasi mengenai teknis pengelolaan usahatani untuk kebutuhan pasar yang masih kurang, tentunya harus diberikan solusi tepat agar kendala dalam pemenuhan produk bagi konsumen dapat diatasi. Menurut Dirjen Horti Departemen Pertanian, pihak pedagang, sebagai pihak yang paling dekat hubungannya dengan petani, harus mulai mengubah "gaya" bisnisnya. Sebaiknya pedagang tidak hanya berdagang, namun turut membimbing petani agar kualitas produk yang diinginkannya sesuai dengan permintaan pasar. Pedagang perantara Pertanian, Volume 1 Nomor 1, April 2012 hlm 33-51

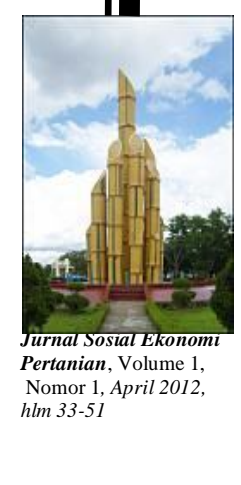




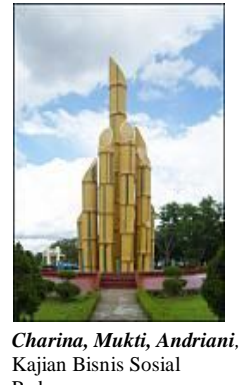

Kajian Bisnis Sosial

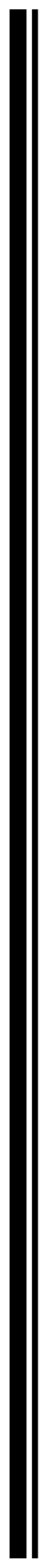

berhubungan langsung dengan konsumen, menyebabkan mereka lebih memahami keinginan atau preferensi konsumen akan produk pertanian. Untuk membina petani, sebagian pedagang juga berlaih peran menjadi pengusaha pertanian (petani) "Baru". Dalam aktivitasnya mereka mulai ikut melaksanakan kegiatan produksi (on farm), sehingga mereka dapat lebih mudah untuk membina petani dengan contoh yang mereka miliki tersebut. Petani kecil di Indonesia pada umumnya memiliki lahan kurang dari $0,5 \mathrm{Ha}$, sehingga mereka kurang berani berisiko dalam usahanya. Hal ini menyulitkan pedagang untuk membina petani dikarenakan petani menjadi kurang respon terhadap segala bentuk informasi yang mengharuskan petani mencoba "cara" baru kegiatan usahataninya. Tingkat keberhasilan yang belum pasti menyebabkan mereka sulit untuk menerapkan teknologi baru di lahannya, sehingga hasil produksi pun secara kualitas dan kuantitas sulit untuk dapat memenuhi standar global.

Pedagang melihat hal tersebut sebagai sesuatu yang sulit untuk dilakukan, namun mereka pun akan kesulitan apabila mereka tetap mengandalkan hasil panen dari petani, karena faktor ketidakpastian yang besar membuat pedagang mulai ikut melakukan kegiatan usahatani. Aktivitas mereka ini merupakan salah satu upaya dari pedagang untuk memberikan contoh kepada petani binaan mereka, karena petani biasanya mau mengikuti sesuatu hal yang baru apabila adopsi inovasi yang dilakukan oleh pedagang terhadap mereka disertai oleh contoh atau demplot yang nyata. Pedagang melihat hal tersebut sebagai kendala dalam aktivitas bisnis mereka, namun sekaligus sebagai peluang usaha yang besar karena pangsa pasar global yang begitu besar.

Berdasarkan kenyataan tersebut, menarik untuk melihat bagaimana mekanisme aturan main yang berlaku dalam hubungan kerjasama / kemitraan antara pedagang dan petani binaannya sehingga proses pembinaan yang dilakukan dapat berjalan sesuai dengan harapan bersama. Selain itu perlu juga dilihat faktor apa yang mendorong mendorong pedagang untuk terjun ke dalam bidang usaha pertanian yang sebenarnya baru bagi mereka. Apakah motif mereka ini murni dikarenakan adanya kesempatan pasar yang luas atau hanya merupakan fenomena jangka pendek saja dikarenakan adanya tingkat keuntungan sesaat yang begitu besar. Apakah motif mereka ini adalah motivasi jangka panjang untuk memperbaiki sisi penawaran produk pertanian untuk merespon peluang pasar global yang besar tersebut. Menarik untuk dikaji alasan bisnis dari para pelaku ini dalam usaha 
mereka untuk meraih pasar global tersebut. Tulisan ini ditujukan untuk membahas motivasi bisnis dari para pedagang perantara tersebut dan menganalisis apakah bisnis yang dijalankan pedagang perantara dapat dikategorikan bisnis sosial atau bukan.

Konsep utama dalam penelitian ini adalah konsep mengenai pedagang perantara. Pedagang perantara adalah orang yang mencari nafkah sebagai pedagang pengumpul hasil pertanian dengan membelinya langsung kepada petani dan kemudian menjualnya, baik di daerah itu sendiri maupun untuk dibawa ke daerah lain, dalam jumlah sedikit ataupun banyak. Pada mulanya yang menjadi pedagang perantara adalah penduduk setempat atau dari desa tetangga yang memiliki lahan pertanian sempit atau bahkan tidak memiliki lahan sama sekali, sehingga untuk mencukupi kebutuhan hidupnya mereka melakukan pekerjaan alternatif sebagai pedagang perantara. Dalam perkembangan selanjutnya banyak pula petani kaya yang menjadi pedagang perantara, terutama dari kalangan muda, karena melihat prospek yang bagus dari usaha ini.

Paradigma berpikir para pelaku usaha saat ini telah memandang pasar sebagai konsumen yang harus dipenuhi kebutuhannya secara optimal, baik kuantitas maupun kualitasnya. Permasalahan yang muncul saat ini adalah, timbulnya ketimpangan informasi antara pedagang perantara dengan petani yang merupakan supplier produk pertanian kepada para pedagang perantara ini. Sebagai sebuah system, tentunya sulit bagi para pedagang untuk berusaha sendiri, namun harus mendapatkan dukungan yang kuat dari petani supplier, sehingga pedagang dapat memperoleh produk pertanian yang kontinu dan juga sesuai dengan aspek yang sesuai dengan permintaan konsumen global.

Untuk menjaga kualitas dan kontinuitas produk pertanian, para pedagang mulai memberikan perhatian lebih kepada petani mitranya, salah satunya adalah memberikan pendampingan kepada petani mitra sehingga pedagang dapat mengendalikan pasokan barang kepadanya.

Berdasarkan kenyataan tersebut,maka perumusan masalah yang dapat diambil dari penelitian adalah :

"Bagaimana mekanisme pedagang perantara memberikan pendampingan dalam aspek on farm kepada petani mitranya untuk memenuhi kebutuhan pasar global serta pengaruhnya terhadap kelangsungan usaha dari petani binaannya tersebut? Apakah bisnis yang dilakukan pedagang perantara dapat dikategorikan bisnis sosial?"

Tujuan dari penelitian ini adalah untuk mengetahui mekanisme pedagang perantara Pertanian, Volume 1 Pertanian, Volume 1,

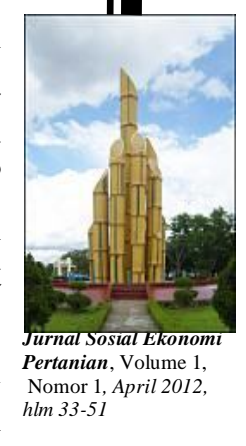




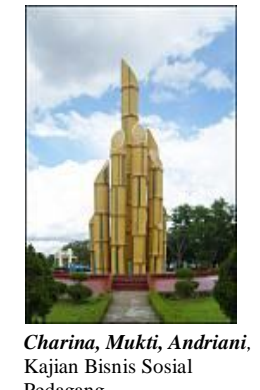

Kajian Bisnis Sosial

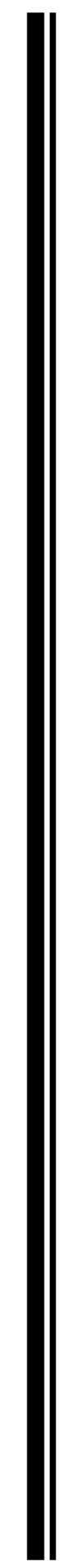

memberikan pendampingan dalam aspek on farm kepada petani mitranya untuk memenuhi kebutuhan pasar global serta pengaruhnya terhadap kelangsungan usaha dari petani binaannya tersebut serta menganalisis apakan bisnis yang dilakukan oleh pedagang perantara dapat dikategorikan bisnis sosial atau bukan.

\section{METODE PENELITIAN}

Teknik penelitian yang digunakan dalam penelitian ini adalah studi kasus, sehingga dapat dihasilkan suatu penjelasan yang kausalitas terhadap kondisi di lapangan dan dapat menjawab pertanyaan "bagaimana" dan "mengapa" sehingga dapat diperoleh hasil kajian yang komprehensif dan dapat menjawab permasalahan yang muncul dalam penelitian ini.

Lokasi penelitian yang dipilih adalah wilayah yang memiliki potensi hortikultura seperti sayuran dan buah buahan. Beberapa wilayah yang dipilih dalam penelitian ini adalah Kabupaten Majalengka, Kabupaten Bandung Barat, Kabupaten Ciamis, dan Kabupaten Bandung. Argumentasi dari pemilihan lokasi ini adalah sebagai berikut:

1) Lokasi penelitian adalah sentra

pertanian/hortikultura di Jawa Barat berdasarkan rekomendasi dari Dinas Pertanian Provinsi Jawa Barat.
2) Pelaku usaha di wilayah kajian tersebut, telah menjual hasil produknya ke pasar, baik itu pasar lokal maupun pasar ekspor.

Adapun responden yang dipilih dalam penelitian ini adalah pedagang perantara yang memberikan pendampingan terhadap petani mitranya. Responden dipilih secara sengaja (purposive) dengan pertimbangan responden adalah orang / pihak yang dianggap kompeten / diperlukan dalam menggali informasi yang dibutuhkan untuk penelitian ini. Responden yang diambil adalah :

1. Pedagang perantara yang bergerak dalam perdagangan hasil pertanian.

2. Pedagang perantara yang memberikan bimbingan kepada mitra binaannya, yaitu petani yang mengirim/menjual barangnya kepada pedagang perantara tersebut.

3. Pihak lain yang dianggap kompeten dan dapat memenuhi kebutuhan informasi dalam penelitian ini.

Rancangan analisis data yang digunakan untuk menjawab pertanyaan penelitian di dalam penelitian ini adalah dengan menggunakan metode analisis deskriptif-kualitatif, yaitu dengan mendetesiskan hasil analisis yang telah dilakukan, seperti wawancara, analisis dokumen/literatur dan temuan studi lain yang tidak terukur, secara kualitatif untuk menjawab 
pertanyaan penelitian (Ozbarlas, 2008). Data yang diperoleh dari lapangan dan yang diperoleh secara desk study dianalisis dengan melakukan interpretasi secara kualitatif terhadap data.

\section{HASIL DAN PEMBAHASAN}

Tuntutan pasar global yang menuntut kuantitas dan kualitas produk pertanian yang semakin baik, membuat pedagang lebih memperkuat hubungan mereka dengan petani produsen yang mensuplai hasil panennya kepada para pedagang, sehingga mereka dapat memperoleh kepastian produk pertanian dari petani. Dalam merespon pasar modern dan ekspor, pedagang mulai melakukan pembinaan kepada petani binaannya, dengan cara ini diharapkan petani dapat menjaga komitmennya dan dapat dipercaya sehingga tidak melakukan kecurangan pada saat melakukan kerjasama dengan pedagang. Dengan adanya pembinaan kepada petani, maka pedagang dapat meminimalisasi resiko dalam hal pasokan barang, sehingga pedagang memperoleh kepastian pasokan dari petani. Oleh karena itu pedagang juga dapat meminimalisasi risiko persaingan usaha, karena ada komitmen bersama antara pedagang dan petani. Selain kepastian usaha, pedagang juga mulai berpikir untuk membantu petani sekitarnya untuk membuka informasi pasar kepada petani, sehingga dapat membuka peluang bagi petani untuk memasarkan produknya lebih luas lagi. Dalam bahasan ini analisa lebih difokuskan untuk mengetahui motivasi bisnis dari pedagang, dilihat dari sisi bisnis social.

Hubungan antara pedagang dan petani binaannya didasarkan hubungan bisnis yang telah lama dijalin, bahkan diantaranya ada yang masih memiliki hubungan keluarga. Antara pedagang dan petani telah tercipta rasa saling percaya dalam bekerjasama, dan diantara pihak tersebut tercipta pula hubungan kekeluargaan. Norma yang berlaku dalam kegiatan bisnis antara pedagang dan petani adalah rasa saling percaya diantara mereka. Sanksi yang berlaku apabila ada salah satu pihak yang mengingkari perjanjian biasanya berupa sanksi social seperti menghentikan untuk sementara order dari petani tersebut atau tidak lagi bekerjasama dengan petani tersebut. Namun kasus ini biasanya terjadi pada petani di luar daerah/kelompok tani binaan yang memang belum memahami kebiasaan/aturan main bisnis yang berlaku.

Dalam menjalankan usahanya, pedagang memberikan pembinaan dalam budidaya yang sesuai dengan SAP/GAP yang sesuai dengan tuntutan pasar,

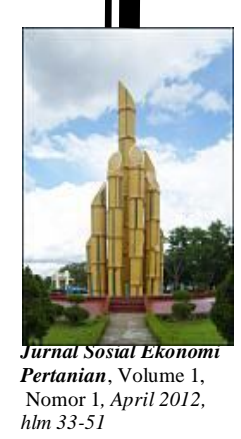




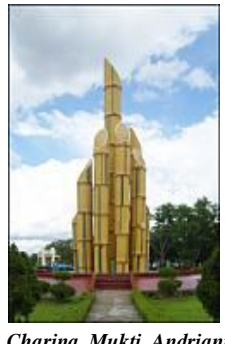

Charina, Mukti, Andriani, Kajian Bisnis Sosia Pedagang... namun petani juga diberi kepercayaan penuh dalam menjalankan usahanya, mereka diberi keleluasaan dalam mengambil keputusan dalam kegiatan usahanya, pedagang memberikan kebebasan kepada petani untuk menerapkannya atau tidak. Hasil dari proses pendekatan ini adalah petani menjadi lebih bisa berinovasi dalam melakukan teknik budidaya yang dirasa lebih efektif dan efisien, dengan kualitas yang tetap terkontrol oleh pedagang dan juga petani. Dalam penentuan harga, pedagang berperan dalam penentuan harga, namun penentuan harga tersebut didasarkan atas perhitungan struktur biaya usahatani yang dilakukan bersama-sama antara pedagang dan petani, sehingga petani merasa tidak dirugikan. Hubungan antar pedagang perantara pun cukup baik dimana pedagang berpikir untuk tidak mengganggu basis produksi milik pedagang yang lain, karena hal tersebut akan menyebabkan hubungan menjadi kurang baik. Para pedagang biasanya saling bekerjasama dalam hal akses pasar dan juga pengadaan barang untuk meningkatkan tarap hidupnya masing-masing dan petani binaan mereka.

Perubahan yang terjadi pada diri petani dengan adanya pendampingan dari pedagang terhadap mereka adalah petani binaan menjadi lebih aktif mengakses teknologi teknis, mulai membiasakan diri untuk melakukan dokumentasi kegiatan sehari - hari melalui proses pencatatan, petani mulai berusaha untuk menjaga komitmen walaupun kadang kadang hal tersebut sulit untuk dilaksanakan karena adanya permintaan pasar dengan tingkat harga yang lebih tinggi. Dengan kondisi ini maka dirasakan oleh pedagang dan petani, lingkungan usaha menjadi lebih sehat, walaupun sesekali tetap saja ada penyelewengan yang terjadi antara sesama pedagang maupun dengan petani, namun masih dalam batas kewajaran yang dapat ditoleransi.

Lewat

penilaian karakteristik bisnis intermediaries, terlihat bahwa intermediaries memiliki jiwa bisnis yang tinggi. Akan tetapi motivasi bisnis sosialnya harus dilihat secara menyeluruh, salah satunya dengan prinsip bisnis social dari M Yunus. Menurut M Yunus, saat ini pedagang baru menilai taraf hidup petani dari sisi pendapatan usaha tani yang pasti yang didapat petani binaannya. Pedagang belum menilai arti "taraf hidup" secara mendalam, bahwa kesejahteraan tidak semata-mata dinilai dari pendapatan. Keamanan, kenyamanan, serta kebermanfaatan sosil belum menjadi point penting yang ingin dibidik atau dituju oleh intermediaries.

Menurut Yunus (2011), tujuh prinsip bisnis sosial adalah:

1. Tujuan bisnis adalah mengatasi kemiskinan, 
atau masalah lain (misalnya pendidikan, kesehatan, akses teknologi, dan lingkungan) yang mengancam manusia dan masyarakat-bukan untuk memaksimalkan keuntungan

2. Perusahaan akan berjalan secara berkelanjutan dalam hal financial dan ekonomi

3. Investor hanya akan mendapatkan kembali uang sejumlah yang diinvestasikannya. Tak ada dividen yang diberikan ketika investasi awal sudah kembali dan perusahaan terus menghasilkan keuntungan

4. Ketika dana yang diinvestasikan dibayar kembali, laba tetap diambil oleh perusahaan untuk perluasan dan perbaikan

5. Perusahaan akan bersikap ramah kepada lingkungan

6. Angkatan kerja mendapatkan upah sesuai pasaran tetapi dengan kondisi kerja diatas standar

7. Dikerjakan dengan senang hati.

Prinsip dasar bisnis social diatas dalam penelitian ini diadaptasikan pada kondisi penelitian untuk keterlibatan intermediaries pada rantai pasokan ke pasar modern dan ekspor kemudian dirubah menjadi pernyataan yang harus direspon dengan jawaban yang diterjemahkan pada skala scoring dan pembobotan.

Hasil pengamatan terhadap aspek bisnis sosial dengan mengunakan kriteria dari Ahmad Yunus dari keempat wilayah kajian adalah sebagai berikut: 
Tabel 2. Analisis Kategori Bisnis Sosial Pedagang Perantara

\begin{tabular}{|c|c|c|c|c|c|c|c|c|c|c|c|c|c|}
\hline \multirow{2}{*}{ No } & \multirow{2}{*}{ Pernyataan } & \multicolumn{3}{|c|}{ Kabupaten Majalengka } & \multicolumn{3}{|c|}{ Kabupaten Bandung } & \multicolumn{3}{|c|}{$\begin{array}{c}\text { Kabupaten Bandung } \\
\text { Barat }\end{array}$} & \multicolumn{3}{|c|}{ Kabupaten Ciamis } \\
\hline & & Bobot & Score & $\begin{array}{l}\text { Total } \\
\text { Score }\end{array}$ & Bobot & Score & $\begin{array}{l}\text { Total } \\
\text { Score }\end{array}$ & Bobot & Score & $\begin{array}{l}\text { Total } \\
\text { Score }\end{array}$ & Bobot & Score & $\begin{array}{l}\text { Total } \\
\text { Score }\end{array}$ \\
\hline 1 & $\begin{array}{l}\text { Usaha dilakukan } \\
\text { guna mengatasi } \\
\text { masalah tidak } \\
\text { terkaitnya petani } \\
\text { dengan pasar } \\
\text { yang } \\
\text { menguntungkan } \\
\text { dan rendahnya } \\
\text { kesejahteraan } \\
\text { petani - bukan } \\
\text { semata mata } \\
\text { untuk } \\
\text { memaksimalkan } \\
\text { keuntungan }\end{array}$ & 2.50 & 2.00 & 5.00 & 2.50 & 3.00 & 7.50 & 2.50 & 2.00 & 5.00 & 2.50 & 3.00 & 7.50 \\
\hline 2 & $\begin{array}{l}\text { Usaha ini berjalan } \\
\text { secara } \\
\text { berkelanjutan, } \\
\text { baik secara } \\
\text { financial maupun } \\
\text { secara ekonomi }\end{array}$ & 1.00 & 3.00 & 3.00 & 1.00 & 4.00 & 4.00 & 1.00 & 4.00 & 4.00 & 1.00 & 2.00 & 2.00 \\
\hline
\end{tabular}




\begin{tabular}{|c|c|c|c|c|c|c|c|c|c|c|c|c|c|}
\hline \multirow{2}{*}{ No } & \multirow{2}{*}{ Pernyataan } & \multicolumn{3}{|c|}{ Kabupaten Majalengka } & \multicolumn{3}{|c|}{ Kabupaten Bandung } & \multicolumn{3}{|c|}{$\begin{array}{c}\text { Kabupaten Bandung } \\
\text { Barat }\end{array}$} & \multicolumn{3}{|c|}{ Kabupaten Ciamis } \\
\hline & & Bobot & Score & $\begin{array}{l}\text { Total } \\
\text { Score }\end{array}$ & Bobot & Score & $\begin{array}{r}\text { Total } \\
\text { Score }\end{array}$ & Bobot & Score & $\begin{array}{r}\text { Total } \\
\text { Score }\end{array}$ & Bobot & Score & $\begin{array}{l}\text { Total } \\
\text { Score }\end{array}$ \\
\hline . & $\begin{array}{l}\text { Pemilik modal } \\
\text { hanya } \\
\text { mendapatkan } \\
\text { kembali uang } \\
\text { sebanyak jumlah } \\
\text { yang } \\
\text { diinvestasikannya. } \\
\text { Tak ada dividen } \\
\text { (keuntungan } \\
\text { bersih) yang } \\
\text { diperoleh pemilik } \\
\text { modal ketika } \\
\text { investasi awal } \\
\text { sudah kembali } \\
\text { dan perusahaan } \\
\text { terus } \\
\text { menghasilkan } \\
\text { keuntungan }\end{array}$ & 2.00 & 3.00 & 6.00 & 2.00 & 3.00 & 6.00 & 2.00 & 4.00 & 8.00 & 2.00 & 3.00 & 6.00 \\
\hline 4 & $\begin{array}{l}\text { Ketika dana } \\
\text { modal yang } \\
\text { diinvestasikan } \\
\text { sudah terbayar } \\
\text { kembali, laba } \\
\text { usaha digunakan } \\
\text { seluruhnya untuk } \\
\text { perluasan dan } \\
\text { perbaikan usaha } \\
\text { bukan untuk } \\
\text { digunakan bagi } \\
\text { pemenuhan } \\
\text { kebutuhan pribadi }\end{array}$ & 2.00 & 3.00 & 6.00 & 2.00 & 3.00 & 6.00 & 2.00 & 3.00 & 6.00 & 2.00 & 3.00 & 6.00 \\
\hline
\end{tabular}




\begin{tabular}{|c|c|c|c|c|c|c|c|c|c|c|c|c|c|}
\hline \multirow{2}{*}{ No } & \multirow{2}{*}{ Pernyataan } & \multicolumn{3}{|c|}{ Kabupaten Majalengka } & \multicolumn{3}{|c|}{ Kabupaten Bandung } & \multicolumn{3}{|c|}{$\begin{array}{c}\text { Kabupaten Bandung } \\
\text { Barat }\end{array}$} & \multicolumn{3}{|c|}{ Kabupaten Ciamis } \\
\hline & & Bobot & Score & $\begin{array}{l}\text { Total } \\
\text { Score }\end{array}$ & Bobot & Score & $\begin{array}{l}\text { Total } \\
\text { Score }\end{array}$ & Bobot & Score & $\begin{array}{l}\text { Total } \\
\text { Score }\end{array}$ & Bobot & Score & $\begin{array}{l}\text { Total } \\
\text { Score }\end{array}$ \\
\hline 5 & $\begin{array}{l}\text { Menerapkan } \\
\text { syarat pada petani } \\
\text { mitra untuk selalu } \\
\text { melakukan } \\
\text { kegiatan produksi } \\
\text { pertanian yang } \\
\text { ramah kepada } \\
\text { lingkungan }\end{array}$ & 0.50 & 3.00 & 1.50 & 0.50 & 3.00 & 1.50 & 0.50 & 3.00 & 1.50 & 0.50 & 3.00 & 1.50 \\
\hline 6 & $\begin{array}{l}\text { Memberikan upah } \\
\text { yang sesuai } \\
\text { dengan pasaran } \\
\text { dan menyediakan } \\
\text { tempat kerja yang } \\
\text { sehat dan nyaman } \\
\text { bagi tenaga kerja } \\
\text { yang dilibatkan } \\
\text { dalam usaha }\end{array}$ & 0.50 & 4.00 & 2.0 & 0.50 & 4.00 & 2.00 & 0.50 & 4.00 & 2.00 & 0.50 & 4.00 & 2.00 \\
\hline 7 & $\begin{array}{l}\text { Berperan menjadi } \\
\text { perantara yang } \\
\text { menghubungkan } \\
\text { petani dengan } \\
\text { pasar modern atau } \\
\text { ekspor ini } \\
\text { memberikan rasa } \\
\text { kepuasan dan } \\
\text { sangat } \\
\text { menyenangkan } \\
\text { hati }\end{array}$ & 1.50 & 2.00 & 3.00 & 1.50 & 3.00 & 4.50 & 1.50 & 4.00 & 6.00 & 1.50 & 2.00 & 3.00 \\
\hline & Total & 10.00 & 21.00 & 28.50 & 10.00 & 23.00 & 31.50 & 10.00 & 24.00 & 32.50 & 10.00 & 19.00 & 28.00 \\
\hline
\end{tabular}




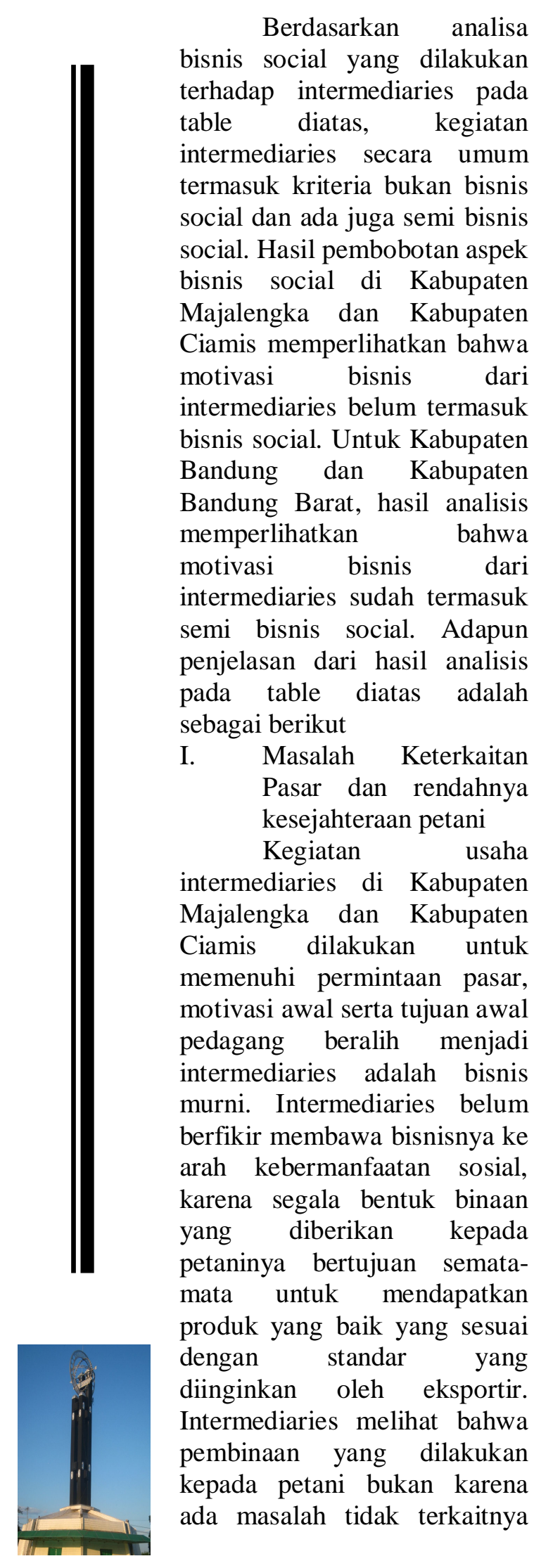

petani dengan pasar yang menguntungkan, namun lebih kepada kepastian pasokan yang mereka butuhkan. Namun demikian, khusus untuk poin bisnis social pertama ini, Intermediaries Kabupaten Ciamis memiliki point yang lebih daripada Kabupaten Majalengka, karena adanya keterikatan yang lebih diantara intermediaries dan petani. Hal ini disebabkan oleh karena intermediaries di Kabupaten Ciamis adalah pedagang local/pribumi, sehingga mereka memiliki sedikit tanggung jawab untuk ikut membantu petani sekitar dalam hal pemasaran produk pertanian mereka. Berbeda dengan intermediaries di Kabupaten Majalengka yang merupakan warga pendatang dari Cirebon atau juga dari Jawa Tengah, yang lebih berorientasi bisnis murni. Mereka membeli produk dari petani berdasarkan fakta bahwa Majalengka merupakan sentra buah di Jawa Barat, bukan karena ingin membuka hubungan antara petani dengan pasar yang menguntungkan. Kegiatan usaha Intermediaries untuk wilayah Kabupaten Bandung dan Kabupaten Bandung Barat, sudah mulai berorientasi sosial (Semi Bisnis Sosial). Intermediaries di Kecamatan Cibodas dan Kecamatan Pangalengan rata-rata merupakan penduduk local, dan mereka yang menjadi intermediaries merupakan tokoh masyarakat yang sudah berhasil ketika mereka masih 


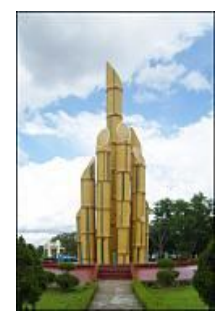

Maswadi, Dampak Penerapan Pungutan Ekspor Crude Palm Oil berusaha sebagai pedagang murni. Sehingga ketika mereka berhubungan dengan pasar global, dengan tuntutan pedagang memiliki petani binaan sendiri, mereka melihat bahwa hal ini merupakan salah satu cara agar mereka dapat mengajak petani di wilayahnya untuk bersama-sama mengisi pasar ekspor ini. Namun demikian, dalam hal keuntungan, para pedagang ini tetap memprioritaskan keuntungan untuk dirinya sendiri, belum semata-mata untuk memaksimalkan keuntungan dari petani mitranya. Hal ini, menurut pengamatan di lapangan dilakukan agar mereka dapat bertahan dalam usaha ini, karena apabila mereka gagal dalam usaha, maka dampaknya adalah petani mitra pun akan turut serta gagal.

II. Keberlanjutan Usaha Dilihat dari aspek keberlanjutan usaha, intermediaries di Kabupaten Majalengka dan Kabupaten Ciamis masih melihat bahwa bisnis mereka adalah kegiatan yang sifatnya dinamis dan jangka pendek. Artinya mereka melihat bahwa, bisnis yang mereka lakukan harus menguntungkan pada saat mereka jalankan, belum melihat keberlanjutan dari usaha yang mereka lakukan. Pada saat ini mereka melakukan pembinaan kepada petani karena mereka melihat pasar ekspor yang masih lebih menguntungkan dibandingkan dengan pasar local, namun apabila situasi usaha kurang mengungtungkan, maka dengan cepat mereka beralih ke jenis usaha yang lain, bahkan usaha non pertanian. Kondisi ini sering terjadi di Kabupaten Ciamis, dimana pada saat harga Cabai di pasar local rendah, maka mereka langsung beralih ke pasar ekspor, namun begitu sebaliknya. Kondisi ini memperlihatkan bahwa usaha mereka sebagai intermediaries yang belum berjalan secara berkelanjutan, terutama dilihat dari segi petani sebagai mitra dari Intermediaries tersebut.

Berbeda dengan kegiatan intermediaries di Kabupaten Bandung dan Kabupaten Bandung Barat, usaha mereka saat ini dapat berjalan secara berkelanjutan. Hal ini terlihat dari komitmen pedagang yang tetap memasok barangnya kepada pasar ekspor/modern, walaupun harga pasar yang tinggi. Hal ini memberikan ketenangan kepada petani mitra binaan karena mereka dapat memiliki kepastian pasar dalam usaha mereka. Sebagai contoh intermediaries di Kecamatan Pangalengan yang tetap konsisten mengisi pasokan Lobak ke pasar ekspor, sehingga petani dapat berusaha secara berkelanjutan.

III. Keuntungan Usaha Dalam aspek keuntungan usaha, intermediaries secara umum berorientasi profit, dimana mereka tetap mengambil keuntungan sebagai hasil usaha mereka. Dari keempat intermediaries, hanya yang di Bandung Barat yang memiliki 
score jauh lebih tinggi dibanding yang Tiga lainnya. Pada umumnya profit tetaplah menjadi milik si intermediarries, dan dimanfaatkan sesuai dengan keperluannya masing-masing, belum ada yang menggunakan atau memanfaatkan profitnya untuk tujuan meningkatkan kesejahteraan petani atau untuk kebermanfaatan sosial bagi lingkungan. Hal ini lah yang menjadi bukti utama bahwa bisnis yang dijalankan intermediaries belum dapat dimasukkan dalam kategori bisnis sosial.

IV. Pengembangan Usaha Intermediaries secara umum menginvestasikan dana modal untuk memperoleh keuntungan bagi mereka sendiri. Secara umum, mereka belum menggunakan laba usaha untuk perluasan dan perbaikan usaha. Perluasan dan perbaikan usaha dilakukan apabila ada peningkatan permintaan dari konsumen, jadi alasan mereka melakukan perluasan dan perbaikan usaha bukan karena ingin mengembangkan usaha bersama, namun masih didasarkan pada pertumbuhan permintaan pasar. Sesuai dengan penjelasan point III (keuntungan usaha), bahwa pada umumnya intermediaries melaksanakan pengembangan usaha untuk kepentingan bisnis semata

V. Kegiatan Produksi Pertanian Yang Ramah Lingkungan

Menurut pengamatan di lapangan, intermediaries saat ini belum menerapkan syarat pada petani mitra untuk melakukan kegiatan produksi pertanian yang ramah kepada lingkungan. Saat ini intermediaries belum menerapkan kegiatan produksi pertanian yang ramah lingkungan karena pasar ekspor dan modern belum mensyaratkan itu sebagai syarat pasokan produk mereka kepada eksportir ataupun pasar modern. Intermediaries memang telah mengurangi kadar pestisida untuk beberapa produk seperti Cabai, Buncis, Baby buncis dan Zuchini, namun alasan utama mereka melakukan ini bukan didasarkan pada aspek lingkungan, namun sematamata dikarenakan permintaan konsumen. Artinya focus intermediaries pada keberlanjutan usaha dengan syarat ramah lingkungan belum sepenuhnya dipahami, karena mereka melihat hal tersebut bukan isu utama namun masih sebatas syarat dagang antara intermediaries dengan pasar global.

VI. Kesesuaian Upah dan Kondisi kerja Pada poin enam dalam prinsip bisnis social ini, intermediaries telah memberikan perhatian yang baik terhadap upah/harga yang proporsional kepada petani dan juga penyediaan tempat kerja yang sehat dan nyaman bagi tenaga kerja yang dilibatkan dalam usaha. Mereka memandang bahwa hal ini merupakan suatu syarat utama untuk menghasilkan produk

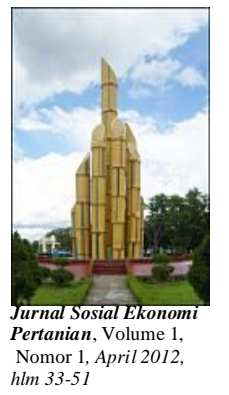




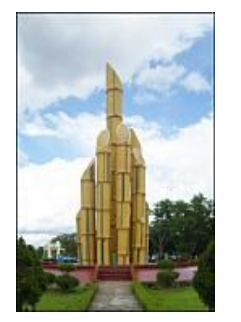

Maswadi, Dampak Penerapan Pungutan Ekspor Crude Palm Oil.. yang dapat diterima oleh pasar, selain itu juga, pekerja yang terlibat dalam kegiatan usaha secara umum masih ada hubungan yang erat dengan pihak intermediaries, baik berupa hubungan keluarga, kerabat ataupun teman. Intermediaries juga telah memahami bahwa tenaga kerja merupakan asset utama dalam usaha, bukan factor produksi yang menjadi beban/biaya bagi mereka.

VII. Kepuasan dalam menjadi Perantara

Analisis dari poin kepuasan dalam menjadi perantara yang menghubungkan petani dengan pasar modern atau ekspor, untuk Intermediaries di wilayah Kabupaten Majalengka dan kabupaten Ciamis, hal ini merupakan yang harus mereka lakukan untuk memenuhi permintaan pasar. Mereka merasa puas karena mereka dapat memenuhi permintaan pasar, bukan karena mereka dapat menghubungkan petani dengan pasar modern atau ekspor. Dalam hal ini terlihat bahwa sebenarnya mereka masih melakukan bisnis murni, belum melakukan bisnis social.

Untuk intermediaries di

Kabupaten Bandung dan Kabupaten Bandung Barat, mereka sudah memiliki kepuasan dalam aspek prinsip bisnis ini. Kondisi yang melatarbelakangi hal ini adalah adanya keterikatan mereka dengan warga sekitar dan juga sebagai pembuktian bagi mereka, bahwa intermediaries ini telah berhasil menembus pasar ekspor dan atau pasar modern. Namun kegiatan ini menurut pengamatan di lapangan, belum sampai taraf menyenangkan hati, karena mereka masih melihat petani mitra adalah asset yang mampu memberikan kepastian pasokan kepada intermediaries, belum memandang mereka sebagai mitra strategis dalam usaha mereka. Hal ini terlihat dari belum optimalnya informasi harga kepada petani mitra, yang artinya masih ada barrier informasi dari intermediaries kepada petani mitra.

\section{KESIMPULAN}

1. Pedagang perantara saat ini telah merubah cara bisnis mereka yang sebelumnya "bisnis murni", menjadi bisnis yang lebih mengutamakan kemitraan dengan petani. Munculnya fenomena ini dikarenakan munculnya tuntutan konsumen, yaitu kontinuitas dalam penyediaan produk hortikultura. Dilihat dari aspek "Bisnis Sosial", secara umum pedagang perantara melakukan ini lebih karena atas dasar kebutuhan kontinuitas barang dari petani,bukan karena sifat social mereka untuk menolong petani. Dari hasil pembobotan total score berkisar antara 28 - 32,5, yang artinya dikategorikan semi bisnis social. Secara keseluruhan, hasil penelitian tersebut 
menunjukkan bahwa saat ini telah terjadi perubahan cara "bisnis" dari pedagang, sehingga hal ini menimbulkan harapan baru akan semakin berkembangnya pertanian di Indonesia, khususnya pada produk hortikultura yang dilakukan oleh pelaku usaha skala kecil.

\section{SARAN}

1. Pembinaan bisnis yang dilakukan oleh pedagang perantara terhadap petani perlu ditopang oleh dukungan pemerintah, sehingga kebermanfaatan sosialnya akan lebih dirasakan oleh petani.

2. Pengembangan usaha hortikultura petani kecil perlu mendapatkan perhatian dari berbagai komponen. Dalam menyongsong era globalisasi, untuk dapat bersaing dengan pasar bebas, diperlukan suatu model rekayasa sosial kelembagaan petani agar memiliki kekuatan untuk tumbuh lebih moderen.

\section{DAFTAR PUSTAKA}

Bouet,A., S. Mevel, and D. Orden. 2007. More or less ambition in the Doha Round:Winners and losers from trade liberalization with a development perspective. The World Economy 30 (8): 1253-1280.

Cline,W. R. 2007. Global warming and agriculture: Impact estimates by country. Washington, D.C.: Center for Global Development and Peterson Institute for International Economics.

Easterling,W.E., $\quad$ P.K. Aggarwal, P. Batima, K.M. Brander, L. Erda, S.M. Howden,A. Kirilenko, J. Morton, J.-F. Soussana, J.Schmidhuber, and F.N.Tubiello. 2007. Food, fibre and forest products. In Climate change 2007: Impacts, adaptation and vulnerability. Contribution of working group II to the fourth assessment report of the intergovernmental Panel on Climate Change, ed. M.L. Parry, O.F. Canziani, J.P. Palutikof, P.J. van der Linden and C.E. Hanson. Cambridge, U.K.: Cambridge University Press.

Ozbarlas, Yesim. 2008. Perspectives on

Multicultural Education:

Case Studies of $A$ German And An American Female Minority Teacher. A Dissertation, not Published. Atlanta: the College of Education in Georgia State University.

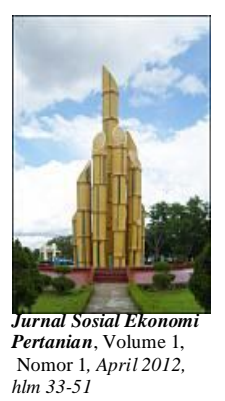




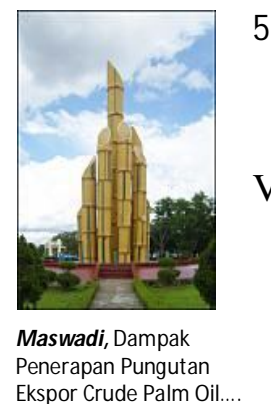

51 Jurnal Sosial Ekonomi Pertanian, Volume 1, Nomor 1, April 2012, hlm 33-51

Von Braun, Joachim. 2004. The World Food Situation. Washington : International Food Policy Research Institute (IFPRI)

Yunus, Muhammad. 2011. Bisnis Sosial - Sistem Kapitalisme Baru yang Memihak Kaum Miskin. Jakarta : PT. Gramedia Pustaka Utama. 